\title{
Pistas sobre el pluralismo religioso y la teología de las religiones (II)
}

\author{
Juan Hernández Pico, \\ Santa María Chiquimula, \\ Guatemala.
}

\section{Teologías desde el tercer mundo}

\subsection{Aloysius Pieris ${ }^{1}$}

Desde Asia, todas las religiones se acercan a la verdad en cuanto proclaman y viven el espíritu de renuncia a Mammón (el dios dinero) y de confianza absoluta en Dios, espíritu que es el único común denominador entre todas ellas. Por eso, al Dios Uno sólo es posible llegar gracias a la mediación de los pobres, en su mayoria no cristianos. La singularidad del cristianismo, descubierta en el intercambio de relatos y en el compartir de luchas, en el seno de las comunidades humanistas de base, consiste en que Jesús es la encarnación del pacto de defensa de Dios con los oprimidos y, por eso, también mediador del camino hacia Dios.

En Diálogo interreligioso y teología de las religiones (1993), escribe que "el diálogo interreligioso... manifiesta en Asia un talante propio y a la vez revela una teología peculiar de la religión". Habla en seguida del trasfondo de este diálogo en los dos magisterios teológicos vigentes dialécticamente en "el patriarcado occidental": el "académico" de los teólogos y el "pastoral" de los obispos y en especial del obispo de Roma. Y habla después del punto de partida de la teología de la religión, en ambos magisterios. "Su punto de partida, y también su marco de referencia, es la cuestión de la 'singularidad cristiana' o también la 'singularidad de Cristo"'. Tanto la crisis religiosa del cristianismo tradicional, en contacto con la creciente secularidad, como el creciente influjo de las religiones orientales plan-

1. Sacerdote y teólogo de Sri Lanka, católico, jesuita, en la tradición de diálogo con el budismo y con las religiones cósmicas de los pobres asiáticos. 
tean "la cuestión de la... singularidad - i[eufemismo] para designar el absolutismo? - de Cristo y su religión... [como] la clave de la teología de la religión que profesa el patriarcado occidental".

Pieris habla enseguida de las tres categorías diseñadas por el magisterio de los teólogos para desarrollar esta teología: "exclusión, inclusión y pluralismo" de las que ya hablaba Torres Queiruga. Opina que "el magisterio pastoral... [por ejemplo en Redemptoris Missio] recela de las tendencias inclusivista y pluralista... capaces de rebajar el viejo espíritu misionero de la Iglesia", y trata de indicar una "sutil regresión... a una postura preconciliar [¿exclusivista?] ante las demás religiones". [Pieris no menciona el magisterio pastoral de Juan Pablo II, en Asís, por ejemplo.] Informa que en Asia se difundieron gradualmente, "en los círculos teológicos... las dos versiones de la postura inclusivista... la del cumplimiento [asumida... por el... Vaticano II] y la de la explicitación [habitual en las décadas postconciliares]". En cambio, aquellos teólogos asiáticos que condenan el exclusivismo y el inclusivismo, por imperialistas, caminaron hacia el pluralismo.

Pieris afirma que se siente "incómodo" dentro de este paradigma "euroamericano". No lo descarta como "erróneo", sino que se ha ido apropiando de otra tendencia vigente en Asia, que no parte de "la singularidad de Cristo o del cristianismo o de cualquier otra religión", ni asume esa preocupación como "propósito oculto en cualquier diálogo interreligioso en que pudiéramos participar", siendo así que, además, considera el mismo diálogo como "un lujo que la urgencia de la crisis socioespiritual de Asia no nos permite". El paradigma alternativo en que se ha ido insertando se construye alrededor de "tres presupuestos que se solapan entre si" y son poco reconocidos "en la perspectiva occidental". Se trata del "magisterio... de los pobres..., la intencionalidad liberacionista que define nuestra teología de las religiones... (y) la ubicación social de esta teología en las comunidades humanistas de base".

Para Pieris, "los pobres [... desvalidos... desposeídos... desplazados... discriminados] que forman la masa de las poblaciones asiáticas [usualmente no cristianas], que profesan... una versión específica de la religión cósmica, constituyen una escuela en la que se reeducan muchos... cristianos en el arte de hablar el lenguaje del Reino de Dios, es decir el lenguaje de la liberación que nos habla Dios a través de Jesús". Pieris cuenta que en 1986, algunos teólogos y obispos hicieron un ejercicio de aprendizaje de los pobres, cuyo propósito "era convencer al doble estamento docente de la Iglesia [programados para aprender muy poco y enseñar mucho] de que debía mantenerse en una actitud permanente de escucha a fin de aprender de los pobres de Asia". Así llegó Pieris a "seleccionar siete rasgos liberadores de la religiosidad 'cósmica' de los pobres":

1. La "vida de oración y [la] espiritualidad" de los pobres "están matizadas por sus necesidades vitales básicas... alimento... trabajo, albergue [y] situación humanamente decorosa", o "con qué... de qué... dónde... y para qué... vivir". 
2. Con respecto a estas necesidades, "los pobres no cuentan con Mammón para solucionarlas... dependen total y absolutamente de Dios. Por eso sólo conocen al Dios del arroz y del curry, un Dios del abrigo y del vestido, un Dios del matrimonio y los hijos... sólo conocen al Dios de esta vida y... de su vida. Esta... es su única espiritualidad".

3. "También invocan a este Dios [generalmente manifestación femenina de lo divino] cuando reclaman justicia... retribución o restitución... aquí en la tierra".

4. "Su postura intramundana ante Dios y la religión... no es secular (el mundo viciado por el ciclo del adquirir y el consumir), sino cósmica", combinación de lo sagrado, lo mujerista y lo terreno, excepto cuando es penetrado por la tecnocracia capitalista.

5. "Las mujeres suelen encontrar... un margen para expresar, al menos simbólicamente, su estado de opresión".

6. "Su espiritualidad se vuelve ecológica", especialmente en el feminismo oprimido, [al reconocer las necesidades terrenas en las matemales fuerzas cósmicas vitales].

7. "El más poderoso medio de comunicación en su tradición religiosa es el relato" de su liberación humana, su única religión: "cómo un Dios se sitúa en medio de su pueblo".

Pieris afirma que "estos ingredientes de la religiosidad cósmica de los pobres han penetrado... en el mundo teológico de los cristianos asiáticos, especialmente entre los teólogos liberacionistas y feministas". Este es un nexo con su segundo presupuesto.

Para mostrarlo, nuestro autor nos dice que "los cristianos nos hemos limitado durante demasiado tiempo a dialogar exclusivamente con las religiones metacósmicas (es decir, con las llamadas formas superiores del hinduismo, el budismo, el taoísmo, el islam, etc.)", mientras que "la religiosidad cósmica (...las religiones clánicas y tribales y también las formas populares de las religiones metacósmicas...) eran miradas... como... etapas inmaduras e infantiles del desarrollo espiritual". Obviamente, esto confronta lo que Torres Queiruga afirma sobre las grandes religiones como más reveladoras que las tribales. ¿Resultado? "Una visión distorsionada del ethos religioso asiático... [y la minusvaloración] del potencial liberador de la religiosidad cósmica".

La verdad es que su "'intramundaridad', junto con su fe en el Dios de justicia, lejos de actuar como un opio (según pensaban algunos marxistas asiáticos), ha resultado ser muchas veces un estímulo en determinadas situaciones revolucionarias", si se da una adecuada movilización de esa actitud. A través de "la común lucha contra la pobreza y el desposeimiento de las masas, han sido muchos los adeptos de las religiones metacósmicas... que han aprendido a rein- 
terpretar... [sus] Escrituras Sagradas... de acuerdo con algunos de los elementos liberadores de la religiosidad cósmica". Entre ellas, también "el cristianismo ha empezado a asumir esa tendencia, pero no en los seminarios o en las casas de las órdenes religiosas, sino en las comunidades humanistas de base, en las que se toma muy en serio el magisterio de los pobres".

Pieris explica así su tercer presupuesto. "Una comunidad humanista de base no es un grupo que se reúne para emprender un diálogo interreligioso... El origen, el desarrollo y la culminación" de estos grupos "tienen como objetivo ideal la liberación total de quienes no son considerados personas o pueblos". Pero, no "a través de la discusión académica", sino "a través de ese proceso... [de] detectar y reconocer tanto el pecado como la liberación según los experimentamos y actuamos sobre ellos". La identidad religiosa de cada persona, incluida la de los cristianos, se va redescubriendo en su singularidad como consecuencia de la interacción mutua. Un marxista de origen budista, muerto luego como mártir a manos de un extremista cingalés, se centró, por ejemplo, en lo que "a través de las luchas compartidas y de las reflexiones comunes [sobre] la literatura religiosa" había descubierto en las Escrituras cristianas: "que el concepto de 'Dios' que impulsa a los cristianos a una actividad liberacionista es radicalmente distinto del concepto de Dios que, según las Escrituras pali, habla rechazado Buda por considerarlo absurdo y quimérico". Y dijo: "si hubiera de creer en Dios alguna vez, éste es el único en quien merece la pena creer". Pieris le respondió: "Creer en cualquier otro dios, como hace la mayoría de los cristianos, es pura idolatría".

El budista-marxista destinado al martirio declaró que ésta era la primera vez que ora "hablar de un Dios que ha sellado un pacto de defensa con los oprimidos". Pero los cristianos de la comunidad humanista de base llegaron así a ver y reconocer que "la singularidad de su religión está en que este pacto se ha encarnado en el Jesús al que seguimos. Pero... [reconociendo también] que... los cristianos tendemos... a copiar los aspectos institucionales de las demás religiones asiáticas para... [competir] con ellas en lugar de predicar y practicar... nuestra misión singular". Esta "experiencia recurrente" nos ha llevado a "comprender por qué una teología asiática de la liberación proclama a Dios como el Uno al que sólo es posible llegar gracias a la mediación de los pobres, no cristianos en su mayor parte, y por qué también proclama que Jesús es esa mediación". Pieris afirma que se trata de "un kerygma que no choca con las demás religiones", ni doctrinal, ni proselitislamente, pero "choca.. con la catequesis oficial de la Iglesia". Pieris no desea rebajar el puesto de la cristología en el kerygma (en lo que tal vez se distingue de algunos teólogos indios). Lo que si hace es recuperar una cristología más sinóptica y menos helenista, que él interpreta así en ¿Universalidad del cristianismo? (1993): "la afirmación de fe de que Jesús encarna el pacto de defensa entre Yahvé y los oprimidos constituye una cristología que puede traducirse en una praxis en Asia y, de hecho, en cualquier otra parte del mundo. Tan sólo esta praxis convierte el cristianismo en una religión universal". 
Aloysius Pieris plantea enseguida la cuestión de la credibilidad. "Que los cristianos vivan conforme a su singularidad y sean reconocidos como tales... dependerá de hasta dónde sean capaces de llegar... en su acuerdo con los adeptos de otras religiones en... el único común denominador entre todas,ellas... el espíritu de desprendimiento o de renuncia a Mammón (...dicho en términos teístas, equivale a una confianza absoluta en Dios)... Se trata de poner en práctica la pobreza evangélica proclamada en el Sermón de la Montaña como elemento integrante de la personalidad del discípulo... [y de] la espiritualidad... del Reino de Dios, la espiritualidad misma de Jesús". Esta credibilidad "está amenazada por... [la] sumisión financiera e ideológica al... poder euroeclesiástico", por ejemplo, cuando las comunidades humanistas de base se vuelven "oenegés" incapacitadas "para dar testimonio de la espiritualidad común [la pobreza por elección]" o cuando las iglesias, desde sus instituciones de caridad, encuentran "más conveniente... [controlar] a los pobres que unirse a ellos en su lucha por la emancipación". Así se hace difícil en las iglesias asiáticas "ejercer su doble función evangelizadora... practicar la solidaridad con los no cristianos", testimoniando "así la espiritualidad común a todas las religiones" y manifestar "su singularidad cristiana... [proclamando] a Jesús como la nueva alianza uniéndose a los pobres contra los principados y potestades de Mamón que generan la pobreza y la opresión".

Pieris cree que "en lugar de esto... [las iglesias] se refugian en una forma de singularidad más confortable que expresan con el modelo teándrico [Dios-Hombre-Salvador] sin sentido en la mayor parte de nuestras culturas [donde] evoca la imagen de una de las muchas formas cósmicas más que la de un Creador-Redentor personal absoluto". Además, "este modelo, absolutamente imposible de traducir a algunos de los lenguajes asiáticos, adolece... de una ontología ante la que la soteriología [la preocupación por la liberación] se desdibuja hasta la insignificancia". Por otro lado, "el anhelo... de los pobres... de un liberador... un Dios capaz de transformar esta tierra, tan claramente expresado en la religiosidad cósmica, es despreciado como un sueño vacío por algunos adeptos de las religiones metacósmicas, que proponen en su lugar otro tipo de 'mundo futuro' coincidente con un cierto modelo de 'absoluto acósmico"”. En cambio, "la historia del acuerdo público de Dios con los pobres para emprender juntos la tarea común de transformar este mundo en el nuevo cielo y la nueva tierra que sueñan juntos Dios y los pobres es la historia que los asiáticos nunca se negarían a escuchar... precisamente la historia que los cristianos temen narrar. Y a pesar de todo, esta historia es el mismo Jesús". ¿Podría decirse que para Pieris el mejor modelo para afrontar la pluralidad religiosa sería el "soteriocentrismo"? Así parece indicarlo su énfasis en la encarnación del pacto de Dios defensa de los pobres en Jesús de Nazaret.

Volviendo al principio, en este paradigma alternativo, las categorfas propuestas por Pieris son: sincretismo (una mezcla aleatoria de distintas religiones, don- 
de resultan alteradas todas, por influjo de las demás); síntesis (la creación de una superación de todas, donde todas pierden su identidad); y simbiosis (todas las religiones, "estimuladas por la postura propia de cada cual" frente a "las aspiraciones liberacionistas de los pobres, y en especial por el relato", acaban redescubriéndose y reformulándose, "en su especificidad como respuesta a las posturas de los demás"). La singularidad cristiana de la que habla Pieris y la conversión a ella son, a la vez, el proceso y el resultado de esta simbiosis, en las comunidades humanistas de base 0 , si se prefiere, de un diálogo interreligioso peculiar.

\subsection{Michael Amaladoss ${ }^{3}$}

La revelación de Dios llega a las personas de tres maneras: la manifestación de Dios en la tradición religiosa, que han recibido de sus antepasados; la manifestación de Dios en Jesús, que les transmiten los cristianos; y su manifestación (a ellos y a nosotros) aquí y ahora, a través de los signos de los tiempos, en particular, a través de los pobres y oprimidos. Las tres pueden entablar una relación y un diálogo de armonía y comunión, cuyo paradigma es (en términos cristianos) la diversidad en la unidad de las tres personas divinas. Los té́logos de la India hablan de que no se debe reducir a Cristo a su presencia en el Jesús histórico, sino que se hace también presente en el Cristo cósmico.

En El evangelio al encuentro de las culturas (1998), escribe que el diálogo interreligioso y la proclamación de la propia fe a personas de otra religión no puede hacerse de forma correcta sin implicarse mutuamente: "en efecto, el diálogo implica dar testimonio de las convicciones propias más profundas y, por otro lado, la proclamación debe respetar la experiencia religiosa y las convicciones del otro". Es así como han ido naciendo los temas de la "nueva teología india".

El primero de todos ellos es "el tema de la liberación". Amaladoss dice que "aunque este interés sea reciente y debido al influjo sudamericano... también la India ha estado marcada por el movimiento de liberación de Gandhi". Tanto la "situación de discriminación y opresión económica y social" como "el contexto religioso del país" han "suscitado una reflexión que ve en la liberación un proyecto interreligioso", llevado a cabo por movimientos, una de cuyas realizaciones son "las comunidades humanas de base", más bien que cristianas.

En el mismo diálogo, "la Iglesia en la India ha aprendido a apreciar [las] riquezas espirituales" de "las demás religiones... especialmente a través de sus

2. Aloysius Pieris, "Diálogo interreligioso y teología de las religiones", en Liberación. inculturación, diálogo religioso, Un nuevo paradigma desde Asia, Estella, 2001, pp. 257-269; " ¿Universalidad del cristianismo?", en Cristianisme y Justicia, Universalidad de Cristo. Universalidad del pobre, Santander, 1995, p. 167.

3. Sacerdote y teólogo indio jesuita, en la tradición del diálogo con las culturas y religiones de la India. 
Escrituras". Y añade: "la exploración teológica ha afimado la inspiración de las otras Escrituras y se ha abierto a la posibilidad de participar en los otros cultos". Todo ello ha desembocado en "una nueva teología de las religiones" que, yendo "más allá de los paradigmas del exclusivismo, el inclusivismo y el pluralismo, llega hasta el paradigma de la unidad en la diferencia, una unidad expresada en símbolos como el de la armonía" de la música cantada o tocada, con sus diversos contrapuntos, por un coro o una orquesta.

Todo esto se basa, según Amaladoss, "en una concepción de la voluntad salvífica universal de Dios que comprende a toda la historia humana... [en] la continuidad entre creación y redención". Por eso, esta nueva teología india "discierne un plan de Dios que conduce todas las cosas del universo hacia la unidad y plenitud". Y es dentro de este plan como "la Iglesia [católica] se ve a sí misma como servidora, histórica, cultural y humanamente condicionada, pero llamada y enviada - 'misionada' - por Dios para ser testigo profético de su plan para el mundo y la humanidad". En consecuencia, "esta nueva concepción ha llevado a la Iglesia de la India a cuestionar las maneras tradicionales de concebir la misión, la revelación, la inspiración, la historia de la salvación, etc.".

Según nuestro autor, "la experiencia de las limitaciones y condicionamientos de la Iglesia [católica] ha llevado a los teólogos [indios] a articular la historia de la salvación conforme a una dialéctica entre Iglesia y Reino de Dios... [viendo] en el Reino una realidad más amplia que la Iglesia y que comprende también a todas las demás religiones". En la misión se trata entonces de "construir el Reino y la Iglesia, ésta como servidora y símbolo de aquél". De manera que, "el objetivo de la misión no es... el de ofrecer la salvación a personas que, sin ella, no podrian alcanzarla, sino el testimonio profético que pone de manifiesto la Alianza de amor entre Dios y la humanidad y que llama a los hombres a una conversión personal, social y estructural", lo cual está bastante cerca de la tesis de Pieris.

Los teólogos indios cuestionan también la tradicional "tendencia a exaltar el carácter histórico del cristianismo y a oponerlo a la naturaleza mítica de las demás religiones", porque esto supone considerar "la historia de una manera lineal como un progreso continuo". Ellos afirman, sí, que "las manifestaciones de Dios en el mundo... no pueden producirse sino dentro de la historia, pero [que] la trascienden también, puesto que lo humano y lo divino no pueden reducirse a lo histórico". Y que la historia no es un proceso de continuo progreso, ha quedado claro después de las trágicas experiencias históricas del siglo XX. Y también avisan que "pretender que una cosa es histórica es pretender también tener cierto poder sobre ella. Hoy [en cambio,] estamos más sensibilizados al misterio de la acción de Dios. Nosotros creamos nuestra historia, pero no del todo, porque la historia es también un don de Dios". Esto significa que, en la historia, hay que "escucharla, colaborar con ella y orar". 
Finalmente, Amaladoss se refiere a la cuestión cristológica. "El cristianismo tiene en Cristo su centro. Pero el cristianismo occidental ha sido exageradamente cristocéntrico y ha intentado fundamentar en Cristo su eclesiocentrismo. Ahora bien, el encuentro con otras religiones no sólo nos ha alejado del eclesiocentrismo [para, por así decirlo, acercamos al reinocentrismo]... También nos ha llevado a caer en la cuenta de la presencia y de la acción del Espíritu en los demás, aunque pertenezcan a religiones y culturas diferentes. Esperemos que esta experiencia nos conduzca a descubrir la presencia del Espíritu y de sus carismas fuera de su marco cristológico y jerárquico, incluso dentro de la Iglesia. De todas maneras, los teólogos indios han empezado a cuestionar la tendencia a reducir a Cristo al Jesús histórico, y hablan del Cristo cósmico".

Amaladoss extiende a la religión popular, lo que Pieris llama las "religiones cósmicas", todo lo que anteriormente dice - probablemente más referido a las "grandes" religiones de la India ("metacósmicas") - y lo radicaliza. "¿Qué hace y qué debería hacer el Evangelio cuando se encuentra con una religión popular? Debería sentirse como en su casa". Y añade: "El Dios de la Biblia era cercano a la gente... Y Jesús hizo lo mismo con sus milagros... Así pues, el Evangelio no debería tener ninguna dificultad con la cosmovisión de la religión popular". Los problemas podrían venir - dice nuestro autor - de la invasión de la modernidad y de su secularidad, así como de que, en ese contexto, "la élite de la Iglesia se vuelve más racionalista [y] más verba]... Es el problema de la liturgia reformada [después del Vaticano II] por medio de la cual se intenta imponer al pueblo una cultura burguesa que favorece las formulaciones verbales respecto a los demás símbolos". También podrían surgir problemas "de reconocer una categoría privilegiada a los símbolos y ritos populares de la Biblia y de las culturas grecolatinas primitivas, en nombre del honor debido a la revelación y a la tradición". Problema más serio sería "considerar como malos y supersticiosos a los símbolos de las demás religiones simplemente por creer que el cristianismo es la única religión verdadera", mientras que "una visión más positiva de las demás tradiciones religiosas... ayuda a reconocer que sus símbolos y rituales pueden ser para la gente verdaderos mediadores de una auténtica experiencia de lo divino". Amaladoss termina previniendo de que en situaciones de conversión religiosa, "una utilización indiscriminada de los antiguos símbolos... puede resultar ambigua". Cabe utilizar "símbolos cósmicos, humanos y sociales, integrados en un contexto cristiano", pero tal vez no "símbolos específicamente religiosos". Da un ejemplo; "aunque los hindúes dicen que [el Dios] 'Shiva bailando' no es sino el símbolo de la actividad creadora y destructora de Dios, los cristianos no utilizarán ese símbolo, pero sí podrán sentirse del todo libres para representar a Cristo Resucitado como a "Cristo bailando"'.

Desde luego, Amaladoss se enfrenta también con la modernidad. También ella ha llegado a Asia y ha sido afirmada y desarrollada con mayor fuerza, si 
cabe, que en el occidente euroamericano. Por eso, constituye un desaffo en Asia. Pero no tiene que ser un desafío idéntico que el que ha supuesto en occidente. Primero, porque la Iglesia en Asia ha sido siempre una minoría y sus concepciones, no obstante el colonialismo imperialista, no han dependido tanto del poder como en occidente. En ese sentido, el choque con la Iglesia y el anticlericalismo no están tan unidos en Asia a un proceso de secularización, que, en Europa sobre todo, nace y se desarrolla, en gran parte, como distanciamiento de la Iglesia. En la India, los cristianos "afiman con fuerza su identidad... de una manera defensiva", en parte, porque la mayoría son dalits, intocables, "aunque la gente comienza a protestar discretamente contra la autoridad absoluta que reclama el clero". Es posible que la secularización sea "la manera como la culeura occidental europea ha reaccionado ante la modernidad. Otras culturas, incluso en parses científicamente avanzados y ricos (como Japón), han reaccionado de manera diferente". Para nuestro autor, la inevitable humildad de la verdad religiosa, en un contexto de tanto pluralismo y la predominancia mayor de la lógica imaginativa del símbolo sobre la lógica intelectual del concepto, hacen a la modernidad en Asia menos amenazadora para la religión. Amaladoss piensa incluso que el desencanto de las nuevas generaciones europeas con la liturgia eclesial se debe a que ésta ha sido incapaz de inculturarse. No obstante, también en la India de las múltiples religiones, puede a veces vivirse como "en dos mundos", porque el ethos de la modemidad es una "orientación que afecta a todas las culturas".

Para nuestro autor "el diálogo [interreligioso] es un proceso de tres caras, y la revelación de Dios llega a las personas de tres maneras: la manifestación de Dios en la tradición religiosa que han recibido de sus antepasados; la manifestación de Dios en Jesús, que les transmitimos; y su manifestación (a ellos y a nosotros) aqui y ahora a través de los signos de los tiempos, en particular a través de los pobres y oprimidos". Y continúa: "el verdadero diálogo entre Evangelio y cultura no se lleva a cabo... a través del misionero..., sino a través de las gentes que escuchan y responden a la Buena Noticia" con plena libertad, dando así origen al pluralismo. El problema es que "no se concede esa libertad..., [pues priva] la preocupación por la unidad". Hay una concepción de la unidad "que provendría de la acción de la Iglesia en el mundo, llevando la Buena Noticia, apropiándose todo lo bueno y verdadero de las demás religiones $\mathrm{y}$, de esta manera, haciéndose universal... como un organismo gigante que lo absorbe todo a su paso". ¿Sería este un peligro en la concepción de la inreligionación de Torres Queiruga?

Para Amaladoss, al elaborar "una correcta concepción de la unidad..., el punto de partida es crucial". ¿Se parte de "un Evangelio y de una Iglesia que se vuelven plurales en diferentes culturas o más bien de unos pueblos numerosos con toda la diversidad de sus tradiciones culturales y religiosas y que responden libremente a la Buena Noticia y convergen hacia la unidad de un solo Dios y de su 
designio universal de salvación para todos los pueblos? La aceptación de las demás religiones como elementos positivos y legítimos de dicho designio divino es... capital en esta nueva concepción".

Para ello, Amaladoss parte de la imagen musical de la armonía, y no tanto de las imágenes neotestamentarias del "templo, cuya piedra angular es Cristo" (1Pe 2, 4-5) - arquitectónica - o del "cuerpo" (1Cor 12, 12-13) y de la "vid" (Jn 15, 1-10) - orgánicas-, en las que el papel de la libertad humana no es fácil de integrar. "Hablar de armonía es utilizar una metáfora musical... [aunque] sólo hay metáfora humana [es decir, que tome en cuenta la libertad humana] si se habla de un coro o de una orquesta". Y sigue: "así tenemos como modelo de pluralismo-en la-unidad no a la materia [el templo o la casa] ni a la vida (el árbol), sino a la comunidad de las personas divinas". "A fin de cuentas, Cristo y el Espíritu son el principio de la unidad en la diversidad". La unidad, en la tradición occidental (continuada, por ejemplo, en Puebla o en el sínodo extraordinario de 1985) se concibe como una "comunión". Si ésta no es, en realidad, pensada jerárquicamente, con la jerarquía como casi única causa eficiente de ella, puede acercarse a lo que Amaladoss sugiere como "armonía". "La amnonía no es una estructura o una institución sino una concepción, un ideal, un fin... [a] realizarse en la Iglesia local con su diversidad de carismas; en la Iglesia universal con su pluralidad de culturas; en la humanidad con sus muchas religiones". En cambio, "no es necesario expresar un principio de armonía en palabras o en estructuras ni tampoco es posible hacerlo. Basta con mirar a la Iglesia hoy en día, unida por sus estructuras y su credo, pero profundamente dividida en su fe real, en su experiencia y en su praxis, como lo muestra todo sondeo contemporáneo". Y termina Amaladoss, "la unidad institucional no es la armonía hacia la que caminamos".

Como criterios del caminar hacia la armonía, Amaladoss señala tres: la nocontradicción de las diferentes expresiones de la fe, no tanto en su estructura lógica cuanto en las actitudes y valores. Luego, el compromiso "con el proyecto de Cristo..., el Reino de Dios", interpretado en los propios contextos y perspectivas plurales. Y finalmente, la verificación del anterior, en la praxis de la "opción por los pobres y oprimidos y en nuestro combate por colaborar con Dios y con los demás en la construcción del Reino de Dios", en la compasión (Mt 25), en las bienaventuranzas vividas (Mt 5) y en los frutos del Espíritu en nuestra vida (Gal 5, 22).

\subsection{Eleazar López Hernández}

Ningún pueblo es dueño absoluto de Dios, sino sólo partícipe de una realidad trascendente, igualmente compartida por otros pueblos. El Dios indio y el

4. Michael Amaladoss, El Evangelio al encuentro de las culturas: Pluralidad y comunión de las iglesias, Bilbao, 1998.

5. Sacerdote y teólogo católico, mexicano zapoteco, en la tradición de diálogo con las religiones y las teologias indígenas de Abya-Yala. 
Dios cristiano son el Mismo, en una y otra experiencia. La fe india, como se expresa en su teología, es una llamada de atención y un testimonio de resistencia digna de pueblos oprimidos. No sólo es la fe india compatible con la fe cristiana, sino que no pocos de los contenidos de la fe cristiana están mejor conservados en la fe india, gracias a la gracia concedida por Dios a los sencillos. La teología india, como todo lo humano, es auténticamente cristiana. Sus horizontes se ensanchan y trascienden, en la fe en Cristo.

Eleazar escribe, en el Prólogo al primer encuentro taller de teología india, que hay que "recordar... un consenso antiguo en la Iglesia: lo que es auténticamente humano es también auténticamente cristiano". Por eso, "en base a este principio sostenemos que una teología auténticamente india es también auténticamente cristiana". Y eso porque "lo indio en el fondo es una llamada de atención a nuestra esencia de hombres y mujeres creados por Dios", sobre todo porque indio es "una categoría" impuesta "desde fuera a los habitantes de Abya Yala para simplificar la dominación europea... una categoría, además de foránea, lesiva a nuestras identidades culturales diversas... en este continente (donde) no habra indios antes de 1492, sino... Navajos, Rarámuris... Zapotecas, Mayas... Kunas... Quechuas... Guaraníes, Mapuches, etc.". Se está llamando "india" a esta teología, con todo, "para indicar la matriz social en que ella es reelaborada a partir de 1492". Por eso, lo indio es "una llamada de atención". Y por eso, "la Teologla India... es una teología de resistencia a la opresión... [porque] es una teología de pueblos oprimidos... más hermanos que antes de $1492 \ldots$ [porque] hoy somos... hermanos de sufrimiento, hermanos de clase social". "Antes de la llegada de los europeos - continúa - ningún pueblo se consideraba dueño absoluto de su Dios; sino sólo partícipe en la visión de una realidad trascendente que era igualmente compartida por otros pueblos; por eso con admirable facilidad podían entrar en contacto con la fe de otros pueblos y sumar sus creencias y símbolos religiosos a los de sus vecinos". Esta reconstrucción histórica no es idnica. También había "guerras y divisiones... entre nuestros antepasados", pero su explicación está - afirma nuestro autor - "al margen de estos anhelos teológicos".

Se pregunta Eleazar si esta teologra es "la que hacen los pueblos indios o la que intentamos hacer los indios en la Iglesia". Y se cuestiona también si "el interés que nos mueve por la recuperación del pensamiento religioso de nuestros pueblos nace de una sincera convicción de que... vale por sí mismo o recibe su valor en cuanto que cabe o puede caber en el marco teológico de nuestras iglesias". Estas preguntas "resultan conmocionantes" para él, pues junto con otros "nosotros estamos escindidos interiormente por un doble amor que no nos deja vivir tranquilos: amamos a nuestro pueblo y creemos en su proyecto de vida. Pero también amamos a la Iglesia y creemos en su proyecto de salvación". Hijos de pueblos que "para sobrevivir han tenido que cavar cepas muy profundas donde guardan sus tesoros o... usar máscaras que esconden su identidad prime- 
ra", e hijos de "iglesias... [con una] práctica misionera... sumamente intolerante frente a las creencias de nuestros pueblos". Esta es la "tragedia que nos empuja constantemente a la tentación de superar el problema con una polarización extrema: o estamos con la lglesia o estamos con nuestro pueblo". Eleazar afirma que existe una convicción de que "es posible - y vale la pena intentarlo- reconciliar los dos amores". Claro que tiene que ser en base a "los planteamientos fundamentales de la Iglesia, que son los mismos de Cristo", lo cual recuerda no insistir en múliples verdades, sino guardar, como dijo el Vaticano II la "jerarquía de las verdades... su conexión con el fundamento de la fe cristiana". Nuestro autor está convencido de que "no hay contradicción insuperable entre los planteamientos fundamentales de la Iglesia... y los planteamientos teológicos de nuestros pueblos... [y de que] los anhelos más profundos de nuestra gente son también los anhelos más profundos de Cristo". Eleazar da un paso más, "muchos de estos contenidos están mejor conservados en nuestros pueblos, por la limpieza de corazón de los pobres, que en muchos recipientes contaminados de la Iglesia".

Al enfrentar la teologfa india, por lo tanto, "nuestra labor... no consiste en querer vestirla de cristianismo; sino mostrar su sentido profundamente cristiano cuando aborda los problemas de la vida, del hombre y de la mujer, del pueblo y de la comunidad, del futuro y del más allá". Así se mostrará que "la compatibilidad entre la fe cristiana y la fe india es asombrosa". Pero, además, se debe afirmar que "para los indios, la fe cristiana tiene que pasar necesariamente por nuestra fe india. Porque no es matando a nuestro Dios como llegaremos al Dios cristiano, sino reconociendo que es el Mismo en una y otra experiencia". Y continúa: "Para encontramos con Cristo es condición indispensable encontramos previamente [ihabría que decir 'o reencontrarnos en nuestras raíces, tal vez antes negadas o relegadas a lo más profundo del inconsciente'? Esto, para ser fieles a la situación real de la evangelización en los pueblos indígenas] con nosotros mismos, con nuestras raíces, con nuestra historia y nuestra cultura y, ¿por qué no decirlo?, con nuestra religión de origen".

La postura de Eleazar es, "Quien no tiene identidad difícilmente podrá tener un encuentro en profundidad con Cristo. Estaría muy expuesto a confundirlo con los ídolos de este mundo". Esta postura, que implica su convicción de que la conversión a Cristo no es "para aniquilarnos o perdernos, sino para ensanchar nuestros horizontes y trascendernos", se explica porque, para él, la teología india se ve "en perspectiva de diálogo en el seno del cristianismo" y como parte de "la Teología Latinoamericana, que es Teología de la Liberación". Pero sea esto así o se prescinda "de este diálogo, es indispensable crear o renovar las condiciones para que la Teología India emerja sin trabas con su rostro y corazón propios. [Y] esto implica, antes que nada, reconstruir el sujeto de ella que son los pueblos indios... [y] trabajar incansablemente para devolver a nuestros pueblos la confianza en sí mismos, el orgullo de su identidad india, la valentía de ser y mostrarse diferentes". 
Finalmente, "la tarea, sobre todo, de quienes, sin ser indios, han optado de corazón por la causa de los pueblos indios", será "construir puentes efectivos de comunicación bilateral, que hagan circular la riqueza de experiencia humana acumulada de un lado y de otro"s.

\subsection{Aiban Wagua'}

Todos los pueblos han recibido una verdad sobre Dios, en su propia historia. Ningún pueblo tiene la propiedad de entender a Dios más que otro. Todos los pueblos son necesarios para poner en una mesa común su experiencia y conocimiento de Dios, que aún así sólo llegará a ser una aproximación de él. El diálogo teológico interreligioso tiene que ser en pie de igualdad. La experiencia y el conocimiento de Dios, desde la historia india, enriquecerá al cristianismo. La fe en Jesús de Nazaret, el Cristo, es un punto conflictivo. Pero todo pueblo y toda religión puede dialogar con ella, con tal que no sea desde el odio, el rechazo o la superioridad, sino desde la conversión al amor.

En Las teologías indias ante la globalidad de la teología cristiona (1991), escribe en forma narrativa, lo que le contó un "anciano teólogo", hablando de lo que entre los kunas es el "aproximado" de nuestro Dios. La conversación responde también a varias preguntas sobre el diálogo interreligioso. "¿Desde las teologras indias podemos hablar de diálogo con otras teologías (no sólo cristianas)? ¿Será verdad que las teologías indias no admiten diálogo? y ¿hasta dónde llega la apertura de las teologfas cristianas?".

Creemos que Paba es una tontería y fácil de ser atrapado. No lo entendemos porque hay odio, hay rechazo de unos a otros. Paba ha creado esta tierra, Nana ha creado esta tierras, estas montañas. Paba es muy grande, es inmenso; Nana es muy grande, es inmensa. No se deja atrapar por un solo pueblo, un solo pueblo no puede conocer todos sus caminos, no puede entenderlo todo. Por eso, Paba creó sobre esta tierra a muchos pueblos. Paba no creó un solo pueblo, Nana no cre6 un solo pueblo sobre esta tierra. Por eso mismo, cuando un pueblo dice "lo que yo sé de Paba es mejor y más exacto", ese pueblo no conoce a Paba; está lejos de entender su mensaje; está creyendo que Paba es poca cosa, que Nana es poca cosa. Los Kunas decimos que Paba está en lo alto, que Nana está en lo alto.

$Y$ es verdad, es una gran verdad. $Y$ no sé qué dirán nuestros amigos negros, pero dicen la verdad. Y aś los otros pueblos que Paba dejó sobre esta tierra.

6. Eleazar López Hemández, "Prólogo", en Teología india, primer encuentro taller latinoamericano, México-Quito, CENAMI y ABYA-YALA, 1991, pp. 5-16.

7. Sacerdote y teólogo católico claretiano, panameño kuna, en la tradición de diálogo con las culturas y las teologías indígenas de Abya-Yala. 
No podemos decir exactamente lo que es Paba, lo que es nana, nunca lo vamos a entender todo.

¿Cuándo, entonces, vamos a conocer mejor a Paba? Nunca en el odio o en el rechazo. Cuando todos nos encontremos desde la diferencia de nuestros pueblos, entonces poco a poco conoceremos a Paba, conoceremos a Nana. Paba no es una tonteria.

\section{Y reflexiona Aiban:}

Para el anciano saila Iguanabiginia las relaciones entre las distintas teologías solamente pueden darse:

Fuera del odio..., del rechazo..., del sentirse unos más que otros, que es lo mismo que convertirse al amor, a la acogida del otro, a la relación de igual a igual como argamasa del diálogo teológico.

Ningún pueblo tiene la propiedad de entender a Paba más que otro. El entendimiento y su profundidad van muy unidos a los acontecimientos, dolores, errores, a la vida diaria de cada pueblo.

La multiplicidad de lenguas, de culturas, de pueblos, son imprescindibles para conocer... las maneras de ser de Paba, de Wiracocha, de Manitú, de Ancore, de Dios.

El desprecio, la muerte, la integración forzada o engañosa de un pueblo... empobrece criminalmente a toda la humanidad, es igual que matar una manera de ser de Paba, de Nana, de Dios, de Yamandú.

En el mundo, cada pueblo conoce solamente una parte de Paba, una parte de Nana..., todos... son imprescindibles para la comprensión definitiva del ser supremo, amado con distintos nombres y vivido desde distintos aspectos.

Paba será Paba, y Nana será Nana, en la medida del equilibrio universal donde cada pueblo ocupará su lugar, en la igualdad de derechos.

Asi, pues, "desde las teologías indias, de forma particular la kuna, el diálogo teológico es necesario, pero en condiciones bien precisas de igualdad. Si no se da esta condición, el diálogo se convierte en conflicto. La teología que se considere mayor, maestra, dueña de la revelación, siempre mirará a las otras como una cenicienta, y se impide así un encuentro positivo y fecundo". Todo se funda sobre la experiencia de Paba y también sobre su concepto: "La teologra kuna parte de la grandeza de Paba. Solamente Paba en su globalidad es la verdad. Cada teología percibe solamente una parte. Para conocer la grandeza de Paba tenemos que unimos, poner en una mesa común lo que para cada teología es su idea de Dios. Incluso teniendo todas las experiencias juntas apenas existe un aproximado de lo que es Paba". 
El punto de partida es caminar hacia el mayor conocimiento o descubrimiento posible de Dios, en la propia religión y cultura, para luego entrar en comunión profundamente humana - lo que dicen los sailas que interesa de verdad a los kunas es "imariscana, lo humano, ser orotule, una humlanidad valiosa". Por eso, "tenemos la obligación de descubrir el rostro de Dios como lo han vivido nuestros padres. Ese rostro los hizo pueblo, les dio identidad... Cuando se conoce bien el rostro kuna del Dios kuna, se puede contemplar bien el rostro blanco del Dios blanco; cuando se conoce bien el rostro blanco del Dios blanco, se puede contemplar bien el rostro kuna del Dios kuna. Son aspectos auténticos de Dios. De otra manera conocemos sólo pedacitos de Dios".

Sin embargo, para Aiban se trasluce tal vez una cierta ambigüedad en esto, pues hay una cierta referencia al mensaje cristiano. ¿Por su propia fe desgarrada, como decía Eleazar, entre el amor a lo indio y el amor a lo cristiano eclesial, es decir, su estado de sacerdote y religioso? $\mathrm{Y}$ así dice: "Si no hacemos esto, no vamos a enriquecer el mensaje cristiano". Pero, en lugar de decir que es la religión kuna la que va a salir enriquecida de su encuentro con el cristianismo, Aiban dice: "Lo indio va a agrandar el conocimiento de Dios". Inmediatamente enfrenta la realidad de la simbiosis, ¿o síntesis?, para usar las categorías de Pieris, histórica de las religiones en América. Y lo dice así, "Aunque en algunas partes este rostro [de Dios] está fundido con imágenes cristianas, en otras se alcanza a distinguir el verdadero rostro del Dios que vieron los viejos, los ancianos". Y termina de una manera que podría llamarse críptica: "Cada pueblo necesita ver a Dios desde su historia. Si alguien ve a Dios desde otra historia, en cierta manera, está mendigando. Yo debo conocer a Dios desde mi historia, y darle la mano a otros que lo ven desde su propia historia; así se amplian las experiencias y las visiones que tenemos sobre Dios" y que entre los kunas no son tanto cosmovision como cosmosentimiento o cosmosensación o experiencia cósmica. Historia y mito están aquí profundamente unidos. Pero hemos aludido a cierta cripticidad, porque, en realidad, ¿cuál es la historia desde la que pueden ver a Dios los pueblos indios de Abya-Yala, después de 500 años de convivencia asimétrica con mestizos y blancos, en la colonia y luego en América Latina?

Finalmente, Aiban toca el punto del Jesús histórico. "Este es un punto conflictivo. Si digo barbaridades recuerden que sólo soy un cartero que [entrego] el mensaje de mi pueblo. Le dije a un saila: 'Yo soy cristiano, creo en Jesús que nació en Belén, que hizo muchas cosas buenas, que murió por nosotros y nos salvó'. El saila me respondió. Bueno. Paba y Nana envió a un hombre que se llama Ibeorgun para hablar a nuestros pueblos, para organizarlos, para que no acapararan cosas, para que fueran generosos, para que supieran vivir, para que compartieran con todo el mundo. Nos dijo cómo vivir unidos, respetando al saila. No vino solo. Vino con su mujer, que enseño a nuestras mujeres a hacer la tinaja, a ocupar su puesto en la sociedad. Esto nos lo enseñó mandado por Paba y Nana. 
Por lo tanto, no necesito lo que enseñas". Y dice Aiban: "Aquí está el problema. La religión kuna se llama religión de Jbeorgun. El está en el pueblo, está en el carto, está en el congreso". Sin embargo, Aiban sintetiza, y no nos dice si lo hace en su nombre o en el del saila o en el de su pueblo, si es su anhelo o también la respuesta que ha visto en su pueblo: "En síntesis, Tú liquién es ese 'Tú'?] dices que me [¿quién es ese 'me'?] anuncias la buena noticia de Jesucristo, que estó en tu cultura. Esta noticia me [¿quién es ese 'me'?] interesa muchísimo [el saila ha dicho antes: 'no necesito lo que enseñas']. Una buena noticia debe ser para rodos los pueblos. Dios no puede quedar sólo en la cultura de un pueblo. Dios no es propiedad de ningún pueblo"в.

\subsection{Engelbert Mveng9}

La herencia espiritual y religiosa de las religiones tradicionales africanas constituye un tesoro único y puede ser una preparación evangélica para el alma africana, tanto mís cuanto que toda experiencia religiosa auténtica se expresa a través de una cultura. En el encuentro con el evangelio hay que asumir esta herencia y superarla. Especialmente, Jesucristo recapitula y lleva a su culminación los modelos de héroe protector y redentor de las religiones africanas. Por eso, también la teología africana es un someterse a juicio ante Dios. Con todo, la experiencia espiritual, eclesial y teológica del cristianismo africano deberá ser inéditamente cristiana. Todo esto se dice desde el clamor de abandono de los africanos, clavados en la misma cruz de Jesús, por el aniquilamiento y el empobrecimiento antropológicos, y por solidaridad con ellos.

En Identidad africana y cristianismo (1999, traducción castellana), escribe que "las religiones tradicionales africanas nos han legado un tesoro único y una herencia de 'familiaridad y de sociabilidad' con el más allá". Y afirma con fuerza que "aquellos que creen, ingenuamente, que la evangelización es una campaña de racionalismo, destinada a combatir la mentalidad hechicera de los negros, no tienen más que ocuparse de sí mismos y de sus fracasos". ¿Cuál es ese "tesoro" y esa "herencia"? Mveng escribe que "en la tradición africana, la realidad fundamental es la vida... [que], en estado puro, se encuentra sólo en Dios, autor y fuente de toda vida. El... cosmos, por el contrario, está constituido por el combate que opone a la Vida contra la Muerte... [Por eso], Dios está más allá del cosmos, más allá de todo enfrentamiento. El hombre aparece como... la recapitulación del cosmos. Todos los mitos, desde las cosmogonías del Egipto faraónico (sobre

8. Aiban Wagua, "Las teologías Indias ante la globalidad de la teología cristiana", en Teologia india, primer encuentro saller latinoamericano, México-Quito, CENAMI y ABYA-YALA, 1991, pp. 291-301.

9. Sacerdote y teólogo católico camenunés, historiador, poeta y artista, jesuita, en la tradición de recreación e inculturación de la Iglesia africana, asesinado en 1995, en Yaounde. 
todo, el mito de Osiris e Isis), lo muestran como el resultado de la génesis misma del mundo".

Continúa Mveng, "el hombre, como el mundo, es enfrentamiento Vida-Muerte; pero tiene una misión que lo convierte en un ser religioso... [e] histórico... asegurar la victoria de la Vida sobre la Muerte. El hombre... es un ser amenazado en su vida. Busca su salvación... En el inmenso campo de batalla del mundo... [su misión] es identificar a los aliados de la Vida, ganarlos para su causa, y garantizar así su supervivencia, que es, al mismo tiempo, la victoria de la Vida". Mveng afirma que "esa es la significación profunda de la religión africana", de sus oraciones, de sus ritos y especialmente de "todos los ritos de iniciación". En ese sentido, afirma Mveng, "la espiritualidad africana aparece... como una espiritualidad de la liberación... [que] se lleva a cabo a través de un mediador..., a la vez modelo y redentor... [y] es fruto de una pasión y de una muerte..., paso de la vida vieja a la vida nueva".

Mveng aborda también la presencia del mal, en esa "herencia" religiosa. "En un mundo donde se enfrenta el Reino de la Vida y el de la Muerte, cada uno de ellos posee sus ejércitos y sus instituciones... el sentido de la verdadera espiritualidad africana... es la liberación con respecto a las fuerzas del Mal, consideradas como fuerzas de opresión. Los rituales de... exorcismo muestran que, si bien el... Mensajero de la Muerte puede intervenir, puede asimismo ser neutralizado por el Mensajero de la Vida, más poderoso que él".

Mveng concluye afirmando que "el problema de la espiritualidad africana aparece asi como un problema cultural. La iniciativa del hombre para alcanzar su salvación está definida por su concepción del hombre, del mundo y de Dios", lo cual define a las religiones africanas como religiones de salvación, más que como religiones animistas, de fusión indeterminada de la vida humana con los espíritus de la naturaleza, que es como no pocos historiadores de las religiones las han delimitado. Aquí, "en un mundo concebido como... esencialmente conflictivo, la noción caballeresca de héroe protector adquiere una importancia primordial... [Los] campeones de la vida" responden a una "vocación... Se trata, a menudo, de personas elegidas desde el seno matemo, marcadas por signos que sólo los Maestros-iniciadores saben descifrar. Están llarnados a llevar una vida de abnegación, de sacrificio, de intercesión a favor de su pueblo". Se trata de una vocación comunitaria: "brota de la comunidad y comparte su destino, sufrimientos y esperanzas". Siendo vocación, afirma Mveng, "la aventura espiritual... se vive sobre todo como ruplura... [0] conversión... el cambio de vida, la muerte al hombre viejo, es el comienzo de toda auténtica iniciativa espiritual. Se cambia de familia, de nombre, de lenguaje... [en] un largo entrenamiento... combate... deporte, a través del cual se moldea el candidato a semejanza del Modelo redentor". "El modelo debe conocer por experiencia la condición humana, haber pasado por la situa- 
ción en que nosotros nos encontramos hoy. Es, a la vez, el caballero sufridor que sabe compadecer, y el caballero vencedor con el que se puede contar".

La herencia religiosa africana tiene también, afirma Mveng, un carácter cósmico: "como el hombre es un microcosmos solidario del macrocosmos, la salvación del hombre es lo mismo que la salvación del cosmos... Los elementos del mundo están divididos en Mensajeros de la Vida y Mensajeros de la Muerte. Los aliados cósmicos de la vida son... los aliados del hombre. Se comprende así el papel sacramental de la naturaleza en el ritual africano. Una vez más, aparece la crítica tácita a las interpretaciones "animistas" de la religión africana. Esta solidaridad permite, además, comprender "la razón de que toda acción civilizadora sea una acción religiosa. La naturaleza, entre... los africanos, no está llena del silencio de Dios. Al contrario, es el lugar del encuentro del hombre con Dios." "El arte africano es, esencialmente, religioso.. [y] desempeña un papel vital... [porque] lleva un solo y único mensaje: la llamada del hombre en busca de su salvación, y el canto de victoria de la Vida sobre la Muerte... La cima de la expresión religiosa africana se encuentra en la música y en la danza... el ejercicio espiritual que purifica, exorciza, suaviza el alma y el cuerpo para hacerlos dóciles a la acción del Espíritu. En África no hay experiencias espirituales sin expresión artística (hasta en los herederos de la esclavitud africana se mira esto, en Estados Unidos, con los spiritual, el jazz o los blues, así como en los orígenes de las experiencias pentecostales)". Finalmente, Mveng habla de la oración, en esta herencia, como "la mejor expresión de la búsqueda de la salvación... [que] expresa a menudo la solidaridad del hombre con la humanidad y el cosmos en la búsqueda de la salvación... [como, por ejemplo, en] la oración de intercesión del monasterio de B'e' ", en Togo.

Mveng piensa que "la herencia religiosa africana, y su expresión cultural, pueden ser así una preparación evangélica para el alma africana... tanto más... [cuanto que] toda experiencia religiosa auténtica se expresa a través de una cultura... En el caso de Africa, el acceso a una experiencia cristiana, debe apoyarse en el Evangelio y en la tradición africana... La formación espiritual en Africa permanecerá estéril en los lugares en que la experiencia religiosa es un lenguaje totalmente extraño". Y en concreto, sobre el rol de Jesucristo, afirma Mveng: "el Modelo Crístico de los Evangelios trasciende, de manera eminente, todos los modelos iniciáticos llevándolos a su plenitud. Establece el puente entre la Vida absoluta y el universo de la Muerte, a través de su condición humana... recapitula y lleva a su culminación toda la tipología del héroe evergete, liberador, salvador, vencedor de la Muerte".

Para Mveng, "lo esencial seguirá siendo siempre la respuesta a la cuestión que Cristo nos dirige a cada uno de nosotros: ' $Y$ vosotros, quién decís que soy yo?'. La teologra para nosotros no puede contentarse con ser un mero ejercicio académico. Es un someterse a juicio ante Dios. Es un Ejercicio espiritual... La 
credibilidad del Evangelio depende de su capacidad de ponernos en contacto con este Dios presente... (el Dios con nosotros), en asumir y superar la herencia de 'familiaridad y sociabilidad' con el más allá que nos legaron nuestros antepasados".

Claro que la teología tendrá que ocuparse también de la "búsqueda de "una eclesiología africana'... de un derecho eclesiástico de las iglesias de Africa... de la materia o la forma de ciertos sacramentos, de los ministerios y de quiénes los ejercen, del matrimonio y la familia, de la catequesis y la educación cristiana, del compromiso político o económico de los cristianos, del diálogo de las religiones en un continente donde el cristianismo es aún minoritario, del ecumenismo para la unidad visible de los cristianos... Las cuestiones que plantea el contexto... de Africa no pueden reducirse a la celebración de la misa con vino de palma, a la 'poligamia cristiana' o al matrimonio a prueba".

Todo esto lo escribe Mveng desde un continente, que describe como "aniquilado antropológicamente", por la trata de esclavos y "empobrecido antropológicamente", por la colonización. "¿Qué dice la Buena Nueva de Jesucristo a las víctimas de la aniquilación y del empobrecimiento antropológico?". Su testimonio es impresionante: "En medio del desconcierto de un mundo dominado por el estrépito de los enfrentamientos 'de bloques hegemónicos', en el seno de una Iglesia aturdida por el estruendo de los medios de comunicación occidentales y la algazara provocada, en el umbral del ocaso del siglo $\mathrm{XX}$ por los vaticinios apocalípticos... le resulta difícil al humilde cristiano de Africa detenerse en las cuestiones esenciales que le conciernen. Con todo ha sonado la hora del cara a cara con Jesucristo... Cuando llegue el día de la verdad, todos estos ruidos desaparecen y nos dejan solos, crucificados con Jesucristo. Entonces sube desde nuestras cruces a su cruz un solo y mismo clamor... ¡Dios mío, Dios mío, ¿por qué me has abandonado? 'Dios habla; tenemos que responderle' y Africa interoga a Dios; preciso es que Dios responda. Ha comenzado el verdadero diálogo"10.

\subsection{Jacques Dupuis"}

La pluralidad de tradiciones religiosas de la humanidad es muestra de la amorosa autocomunicación de Dios, "muchas veces y de muchas maneras" en la historia. La unicidad de Jesucristo es "constitutiva" para la salvación de toda la humanidad, pero no es absoluta, ni relativa, sino relacional a la gracia y la verdad comunicadas por Dios a las diversas tradiciones religiosas. El cristianismo y las otras tradiciones religiosas son complementarias potencialmente. Su potencialidad puede actualizarse a través del diálogo interreligioso

10. Engelbert Mveng, Identidad africana y cristianismo, Estella, 1999, pp. 283, 64-70 y 282-283.

11. Sacerdote y téblogo católico belga, profesor en la India y la Gregoriana, en la tradición jesuita de pensamiento sobre las religiones no cristianas y el diálogo con ellas. 
y la comunión en la participación del camino hacia el reino de Dios. Además, son convergentes. Pero esta convergencia es escatológica y llevará a plenitud la gracia y la verdad del cristianismo y de las otras religiones, "cuando Dios sea todo en todos".

En la "Conclusión" de su obra monumental Hacia una teología cristiana del pluralismo religioso, escribe que "por una 'teología cristiana' entendíamos una teología que reflexionase sobre la pluralidad de las religiones en nuestro mundo actual, colocándose dentro de la perspectiva de la fe cristiana, pero adoptando al mismo tiempo una visión global que tuviese en cuenta la complejidad de la realidad religiosa como se vive hoy". Y al final de su larga "inducción dialógica y comparativa", Dupuis recuerda algunas "claves de interpretación" de la parte de su trabajo propiamente sistemática. Son tres.

La primera es "la relación mutua y la implicación rećproca de varios modelos, vistos a menudo erróneamente como paradigmas recíprocamente exclusivos: el cristocentrismo, el teocentrismo, el reinocentrismo, el soteriocentrismo y otros. Separar estos aspectos es captar de forma incompleta la complejidad y la riqueza de la experiencia cristiana".

Una segunda clave de interpretación es "una cristología trinitaria y del Espíritu... [que] ha hecho posible poner el acento en la universalidad de la presencia activa de la Palabra de Dios y de su Espíritu, como fuente de iluminación y de inspiración de los fundadores religiosos y de las tradiciones que han brotado de su experiencia". Esta clave ha sido aplicada a cuestiones como "la revelación divina y la autodonación de Dios en la salvación, los diversos rostros del Misterio divino y las (diversas) figuras salvíficas". Así, Dupuis ha podido "ver el misterio de la autorrevelación de Dios en Jesucristo, como realidad esencialmente relacional con respecto" a la obra de Dios, en la historia pasada, actual y futura.

La tercera clave ha sido "el modelo reinocéntrico, que... ha hecho posible concebir" la coparticipación del "cristianismo y las otras tradiciones religiosas", en "la realidad universal del reino de Dios, en cuya construcción son llamados a colaborar hasta su plenitud escatológica". Con ello se puede llegar a "una visión más verdadera de la lglesia como 'sacramento del reino' y de su misión al servicio del reino, en la que se incluye el diálogo interreligioso".

Dupuis intenta después responder a tres cuestiones repetidamente levantadas en su obra.

La primera cuestión es el sentido del pluralismo religioso. ¿Se trata de una realidad sólo de facto o "puede ser visto teológicamente como realidad existente de iure? En el primer caso se trataría de algo con lo que hay que contar, en parte "por el parcial fracaso de la misión cristiana, especialmente en Asia"; y esto, aunque produzca malestar. En el segundo caso, la misma pluralidad se debería "a la sobreabundante generosidad con que Dios se ha manifestado de 
muchos modos a la humanidad y la multiforme respuesta que los seres humanos han dado en las diversas culturas". Y continúa Dupuis, inclinándose por esta segunda eventualidad: "Si... la religión tiene su fuente originaria en una automanifestación divina a los seres humanos, el principio de la pluralidad encontrará su fundamento primario [no tanto en la pluralidad de personas en el único Dios, ni menos en el carácter plural de toda realidad, ni en los límites innatos de toda comprensión humana del Misterio divino, sino] en la sobreabundante riqueza y diversidad de las automanifestaciones de Dios a la humanidad... El hecho de que Dios hubiese hablado 'muchas veces y de muchas maneras' antes de hablar por medio de su Hijo (Hb l, l) no es accidental; tampoco... es una mera cosa del pasado... El carácter decisivo de la venida del Hijo en la carne de Jesucristo no suprime la presencia y la acción universales de la Palabra y del Espíritu. El pluralismo religioso se fundamenta sobre la inmensidad de un Dios que es amor".

La segunda cuestión es el significado del carácter relacional de la unicidad y la universalidad de Jesucristo, que Dupuis ha sostenido en su obra, "conforme a la corriente principal nunca interrumpida de la tradición cristiana... [que] asevera que la persona de Jesús y el acontecimiento Cristo... (en particular el acontecimiento de su muerte-resurrección] son 'constitutivos' de la salvación para toda la humanidad... independientemente de su situación histórica". Aquí se toca el núcleo de la cuestión principal: "Jesucristo, hijo de Dios hecho carne, es el sacramento de la voluntad salvífica universal de Dios". Sin embargo, "tal unicidad no debe ser interpretada como absoluta: lo absoluto es la voluntad salvífica de Dios. La unicidad de Jesús no es absoluta, ni relativa, sino 'constitutiva'; además es 'relacional'".

Dupuis se pregunta por el sentido de esa unicidad relacional. Y trata de responder de esta manera. "El acontecimiento histórico de la encarnación de Dios marca la más profunda y decisiva implicación de éste con la humanidad... una unión (con el género humano) que no se podrá romper jarnás". Pero este acontecimiento lleva la marca de los límites de todo acontecimiento histórico humano - si no, se perdería su densidad real-, "a pesar del carácter "transhistórico' de la humanidad resucitada de Jesucristo". El acontecimiento Jesucristo es "particular en el tiempo y universal en el significado; y, como tal, 'singularmente único', pero en relación con todas las demás manifestaciones divinas a la humanidad en una única historia de salvación; es decir, relacional".

¿Cómo se integra esta reflexión en los famosos paradigmas? Con ella "se hace posible superar no sólo el paradigma exclusivista, sino también el inclusivista, sin recurrir al paradigma 'pluralista' basado en la negación de la salvación constitutiva en Jesucristo". ¿Y qué de las otras automanifestaciones de Dios, presentes en otras religiones? Responde Dupuis: "la verdad y la gracia que se encuentran en otras partes... (gracias a la cristología trinitaria, la iluminación 
universal por parte de la palabra de Dios y la vivificación por parte de su Espíntu)" pueden ser "elementos no explicitados con el mismo vigor y claridad en la ręvelación y manifestación de Dios en Jesucristo". Por tanto, "no deben quedar reducidas a 'semillas' o 'escalones' que deben ser simplemente utilizados y después sustituidos en la revelación cristiana. Representan beneficios adicionales y autónomos", respecto a la revelación cristiana. "Como 'rostro humano' o 'icono' de Dios, Jesucristo confiere al cristianismo su carácter específico y singular. Pero, aunque es constitutivo de la salvación de todos, no excluye ni incluye otras figuras o tradiciones salvíficas. Si consuma la historia de la salvación, no es a título de sustitución o reemplazo, sino como confirmación y realización".

La tercera cuestión se refiere al modo como el cristianismo y las demás tradiciones religiosas son complementarias y convergentes. Dupuis ha hablado en su obra varias veces de complementariedad, por ejemplo, de "los rostros del Misterio divino propuestos por otras tradiciones... y el misterio de la Trinidad... revelado en Jesucristo... [0] cuando se han descubierto en otros 'caminos de salvación' valores complementarios a los propuestos por el 'camino' cristiano". Y profundiza este punto, diciendo que "se trata de una complementariedad reciproca (no como si aquellos valores estuviesen destinados a ser simplemente 'integrados' en el cristianismo)... de un enriquecimiento mutuo".

Precisamente, "la complementariedad mutua hace posible una convergencia mutua", cuya potencialidad puede ir volviéndose más actual, a través del diálogo interreligioso, con sus exigencias "de... experiencia religiosa y de discurso teológico". Pero también por el "misterio de la comunión en el Espíritu existente entre los interlocutores del diálogo, que brota de su coparticipación en la realidad universal del reino de Dios". Dice Dupuis que "esta comunión anticipada garantiza la posibilidad de la efectiva convergencia por medio del diálogo".

Dupuis termina hablando del carácter escatológico de esta convergencia. "El diálogo entre las fes contribuye... a la construcción del reino de Dios en la historia. Pero éste [el reino] sigue ordenado... a su plenitud escatológica al final de los tiempos". "En el eschaton tendrá lugar una 'recapitulación' (anakephalaiosis Ef 1,10$)$... en Cristo de las tradiciones religiosas del mundo... [Y] coincidirá con la 'perfección' última (teleiosis) del Hijo de Dios como 'causa de salvación eterna' (Hb 5, 9), cuya influencia sigue sujeta, hasta la consumación final, a una 'reserva escatológica'. Una vez realizado el reino de Dios, tendrá lugar el fin, 'cuando... [Cristo] entregue el reino a Dios Padre; entonces 'el mismo Hijo se someterá también al que le sometió todo' y Dios será 'todo en todas las cosas' (1Cor 15, 24-28)".

Dupuis recupera al final la "maravillosa convergencia" teilhardiana "de todas las cosas y todas las tradiciones religiosas en el reino de Dios y en el Cristo omega... Tal convergencia escatológica no ensombrece en modo alguno el acontecimiento histórico de Jesucristo: él es el fin (omega) porque es el principio 
(alpha), el 'eje central'... La plenitud escatológica del reino de Dios es la consumación final común del cristianismo y de las otras religiones"'/2.

Continuará en el proximo número con el análisis del tema en los documenros doctrinales eclesiales (Vaticano II, Pablo VI, Juan Pdblo II) y en las congregaciones generales XXXII, XXXIV y XXXV de la Compañía de Jesús.

12. Jacques Dupuis, Hacia una teologia cristiana del pluralismo religioso, Santander, 2000, pp. 565-572. 